\title{
Najważniejsze zmiany w diagnostyce agresywnych chłoniaków z komórek B według klasyfikacji Światowej Organizacji Zdrowia z 2017 roku
}

\author{
The most important changes in the diagnosis of aggressive \\ B-cell lymphomas according to the World Health Organization \\ 2017 classification
}

\author{
Anna Szumera-Ciećkiewicz, Monika Prochorec-Sobieszek \\ Zakład Diagnostyki Hematologicznej, Instytut Hematologii i Transfuzjologii, Warszawa
}

\begin{abstract}
Streszczenie
W 2017 roku wprowadzono zaktualizowana, 4. edycję klasyfikacji nowotworów uktadów chtonnego i krwiotwórczego opracowana przez Światowa Organizacje Zdrowia. Część znaczacych zmian dotyczy aktualizacji danych obejmujacych biologie, patomorfologie, genetyke i cechy kliniczne agresywnych chtoniaków z dojrzatych komórek B. Wprowadzono nowe jednostki (chtoniaka o wysokim stopniu ztośliwości z komórek B i chtoniaka burkittopodobnego $z$ aberracja 11q), zmodyfikowano istniejace (chtoniak rozlany $z$ dużych komórek B, bliżej nieokreślony, EBV+), a także utrzymano niektóre określenia tymczasowe (nieklasyfikowalny chtoniak z komórek $B, z$ cechami pośrednimi między chtoniakiem rozlanym $z$ komórek $B$ a klasycznym chtoniakiem Hodgkina). Istotny postęp w zakresie technik biologii molekularnej oraz genetyki przektada sie na ich praktyczne wykorzystanie $w$ diagnostyce rutynowej chtoniaków. Obecnie poprawne rozpoznanie chtoniaka o wysokim stopniu ztośliwości z komórek B, oprócz diagnostyki patomorfologicznej i immunohistochemicznej wymaga określenia statusu genów C-MYC, BCL2 i BCL6. Stanowi to istotne wyzwanie dla reorganizacji rutynowej diagnostyki, miedzy innymi ze wzgledu na ograniczony dostep do wystandaryzowanych technik molekularnych/genetycznych i określenie finansowania tych badań. Najistotniejszym czynnikiem pozostaje zaangażowanie wyspecjalizowanego zespotu lekarzy i techników zapewniajacych odpowiednie pobranie $i$ zabezpieczanie materiatu biologicznego oraz jego opracowanie różnymi technikami, co przektada się na możliwość wydania petnego wyniku zawierajacego wtaściwe rozpoznanie.
\end{abstract}

\section{Słowa kluczowe: agresywne chłoniaki z dojrzałych komórek B, klasyfikacja, diagnostyka histopatologiczna, biologia molekularna i genetyka chłoniaków}

Hematologia 2018; 9, 1: 1-14

\section{Abstract}

In 2017, the revised $4^{\text {th }}$ edition of the classification of tumors of hematopoietic and lymphoid tissues developed by the World Health Organization was introduced. Some of the significant changes concern the updating of data covering biology, pathomorphology, genetics and clinical features of aggressive lymphomas from mature B cells. New entities have been introduced (high grade B-cell lymphoma and Burkitt-like lymphoma with 11q aberration), some of existing ones have been

Adres do korespondencji: Monika Prochorec-Sobieszek, Zakład Diagnostyki Hematologicznej, Instytut Hematologii i Transfuzjologii, ul. Indiry Gandhi 14, 02-776 Warszawa, e-mail: monika.prochorec@interia.pl 
modified (EBV-positive diffuse large B-cell lymphoma, not otherwise specified) and some provisional definitions (unclassified B-cell lymphoma, with intermediate features between diffuse B-cell lymphoma and classic Hodgkin's lymphoma) have been retained. Significant progress in the field of molecular biology techniques and genetics translates into their practical use in the routine diagnosis of lymphomas. Currently, the correct diagnosis of high-grade B-cell lymphoma in addition to pathomorphological and immunohistochemical diagnosis requires the determination of status $C-M Y C, B C L 2$ and BCL6 genes. This is a significant challenge for the reorganization of routine diagnostics. This is influenced by limited availability of standardized molecular/genetic techniques and determination of funding for these studies. The most important factor still remaining is the involvement of a specialized team of doctors and technicians ensuring adequate collection, protection of biological material and its development by various techniques, which translates into the possibility of issuing a full result including proper diagnosis.

\section{Key words: aggressive lymphomas from mature B cells, classification, histopathological diagnosis, molecular biology and lymphoma genetics}

Hematologia 2018; 9, 1: 1-14

\section{Wprowadzenie}

Agresywne chłoniaki z dojrzałych komórek B stanowią heterogenną grupę chorób charakteryzujących się unikatowymi cechami biologicznymi i patomorfologicznymi oraz obrazem klinicznym. Niektóre $z$ nich występują często, inne pojawiają się rzadziej i dotyczą wyłącznie określonych grup pacjentów. Rokowanie i odpowiedź na leczenie są różne i mimo stosunkowo wysokiej skuteczności stosowanych obecnie schematów terapeutycznych nadal około $30 \%$ pacjentów przechodzi w stadium nieuleczalnej choroby. Wyniki badań genetycznych i molekularnych przeprowadzonych w ostatnich latach pozwalają na lepsze zrozumienie mechanizmów leżących u podstaw różnorodności klinicznej i biologicznej tych nowotworów oraz dostarczają cennych informacji o nowych możliwościach terapeutycznych. W zaktualizowanej w 2017 roku klasyfikacji Światowej Organizacji Zdrowia (WHO, World Health Organization) nowotworów układu chłonnego uwzględniono najnowsze dane dotyczące cech klinicznych oraz biologii, patomorfologii i genetyki agresywnych chłoniaków $z$ dojrzałych komórek $\mathrm{B}$, co przełożyło się na modyfikację kryteriów diagnostycznych [1-3]. Chłoniak rozlany z dużych komórek B, bliżej nieokreślony (DLBCL, NOS, diffuse large B-cell lymphoma, not otherwise specified) jest najczęściej (ok. 30\% wszystkich chłoniaków nie-Hodgkina) występującym podtypem wśród agresywnych chłoniaków $z$ komórek B. Kategoria ta obejmuje DLBCL, których nie można zaklasyfikować jako żadnej innej lepiej zdefiniowanej jednostki. Inne agresywne chłoniaki z dojrzałych komórek B są mniej rozpowszechnione, ale mają charakterystyczne cechy kliniczno-patomorfologiczne. Chłoniak $z$ dużych komórek B bogaty w limfocyty T/histiocyty (THRLBCL, T-cell/histiocyte-rich large B-cell lymphoma) ma charakterystyczny obraz mikroskopowy; nieliczne komórki nowotworowe są rozproszone pojedynczo wśród obfitego podścieliska z obecnością dominujących komórek odczynowych. Niektóre agresywne chłoniaki $z$ dużych komórek B są klasyfikowane ze względu topografię. Może się to wiązać $z$ charakterystycznym typem komórek w danej lokalizacji lub wpływem mikrośrodowiska na patogenezę. Wyodrębniona grupa chłoniaków $z$ dużych komórek B (LBCL, large B-cell lymphoma), która jest związana $z$ infekcją wirusem Epstein-Barr (EBV, Epstein-Barr virus) występuje $\mathrm{u}$ chorych $\mathrm{z}$ zaburzeniami immunologicznymi upośledzającymi kontrolę zakażeń wirusowych. Większość LBCL charakteryzuje fenotyp dojrzałych limfocytów B lub różnicowanie plazmablastyczne, którego cechą wyróżniającą jest utrata markerów limfocytów $\mathrm{B} z$ równoczesną silną ekspresją białek związanych $z$ komórkami plazmatycznymi. Niektóre $z$ tych nowotworów są związane $z$ zakażeniem ludzkim wirus opryszczki typu 8 (HHV8, human herpesvirus type 8/Kaposi sarcoma-associated herpesvirus) i/lub EBV. Chłoniak Burkitta (BL, Burkitt lymphoma) jest dobrze zdefiniowanym wysoce agresywnym chłoniakiem o korzystnym rokowaniu. Tym niemniej, zgodnie $z$ wynikami złożonych badań genetycznych, możliwe stało się doprecyzowanie mechanizmów aktywacji genu $M Y C$. W tej kategorii pojawiła się też nowa tymczasowa jednostka „chłoniak burkittopodobny z aberracją 11q" (Burkitt-like lymphoma with $11 q$ aberrations). W klasyfikacji 
WHO z 2017 roku wycofano kategorię chłoniaków agresywnych $z$ komórek $\mathrm{B} z$ cechami pośrednimi między DLBCL i BL oraz wprowadzono, uzależniony od wyników badań genetycznych, podział na chłoniaka o wysokim stopniu złośliwości z komórek $\mathrm{B} z$ rearanżacjami $M Y C$ i $B C L 2$ i/lub $B C L 6$ (HGBL, $M Y C-R$ and BCL2-R and/or BCL6-R; High-grade $B$-cell lymphoma, with MYC and BCL2 and/or BCL6 rearrangements) i chłoniaka o wysokim stopniu złośliwości z komórek B, blizzej nieokreślonego (HGBL NOS, high-grade B-cell lymphoma, NOS). Ponadto $\mathrm{w}$ diagnostyce różnicowej agresywnych chłoniaków B-komórkowych należy uwzględnić chłoniaka $z$ komórek płaszcza, wariant o morfologii blastoidnej lub pleomorficznej (MCL, mantle cell lymphoma, blastoid or pleomorphic variant), którego cechą charakterystyczną jest występowanie translokacji $t(11,14)$ (q13;q32) znajdującej odzwierciedlenie w nadekspresji cykliny D1. Utrzymano natomiast kategorię nieklasyfikowalnego chłoniaka $z$ komórek B, $z$ cechami pośrednimi między chłoniakiem rozlanym z komórek B a klasycznym chłoniakiem Hodgkina (BCLu-DLBCL/cHL; B-cell lymphoma, unclassifiable, with features intermediated between diffuse large B-cell lymphoma and classic Hodgkin lymphoma). $\mathrm{W}$ tabeli 1 podsumowano typy histopatologiczne agresywnych chłoniaków z dojrzałych komórek B w zaktualizowanej klasyfikacji WHO z 2017 roku.

\section{Chłoniak rozlany z dużych komórek B, bliżej nieokreślony}

Chłoniak rozlany $z$ dużych komórek B, bliżej nieokreślony jest heterogenny klinicznie i biologicznie. Badania profilu ekspresji genów (GEP, gene expression profiling) pozwoliły na identyfikację dwóch molekularnych podtypów o odmiennym pochodzeniu komórkowym (COO, cell of orgin) z komórek ośrodków rozmnażania (GCB, germinal center $B$-cell) lub $\mathrm{z}$ aktywowanych komórek $\mathrm{B}$ (ABC, activated $B$-cells). Podtypy te różnią się także rodzajem aktywowanych ścieżek - molekularnych, zmianami chromosomalnymi i występowaniem mutacji somatycznych [4-6]. Różnice biologiczne przekładają się na inny przebieg kliniczny; w większości badań wykazano gorsze rokowanie u chorych na DLBCL ABC niż DLBCL GCB (40-50\% v. 70-80\% 5-letni czas wolny od progresji choroby [PFS, progression-free survival] w przypadku terapii wg schematu R-CHOP [rytuksymab, cyklofosfamid doksorubicyna winkrystyna prednizon]) [7]. W DLBCL GCB obserwuje się głównie aktywację ścieżki sygnałowej 3-kinazy fosfatydyloinozytolu (PI3K, phosphatidylinositol 3-kinase) i nadekspre- sję BCL6, natomiast w DLBCL ABC występuje konstytutywna aktywacja ścieżki sygnałowej czynnika jądrowego kappaB (NF- $\kappa \mathrm{B}$, nuclear factor $\kappa B)$ w przebiegu różnych mechanizmów. Zmiany genetyczne w DLBCL GCB obejmują rearanżacje genów $B C L 2(40 \%)$ i BCL6 (25-30\%) oraz mutacje w genach biorących udział w regulacji epigenetycznej: EZH2 (20-25\%), KMT2D/MLL2 (40\%), CREBBP (30\%), GNA13 (25\%), natomiast w DLBCL ABC występują częściej mutacje w genach $M Y D 88$ (35\%), CARD11 (15\%) i CD79B (20-25\%) [8, 9]. Wyodrębnienie różnic w patogenezie molekularnej obu podtypów może prowadzić w przyszłości do zastosowania specyficznych terapii celowanych. Wyniki badań klinicznych I i II fazy sugerują korzyści $z$ dodania bortezomibu, lenalidomidu i ibrutynibu do schematu R-CHOP $w$ terapii DLBCL $\mathrm{ABC}$ [10-12]. Ze względu na znaczenie kliniczne obecnie rekomenduje się utrzymanie rozpoznania wyżej wymienionych podtypów i w rutynowej diagnostyce patomorfologicznej nadal zaleca się stosowanie algorytmu Hansa opierającego się na panelu przeciwciał (CD10, BCL6, IRF4/MUM1) oznaczanych metodą immunohistochemiczną (IHC, immunohistochemistry), mimo że zgodność z klasyfikacją molekularną określaną techniką profilowania genetycznego wynosi jedynie 80-90\% [5, 13]. Ograniczenia metody IHC wiążą się $z$ trudnościami w standaryzacji barwień i zmienną powtarzalnością wyników oceny wśród patomorfologów. Ponadto należy pamiętać, że w około $10 \%$ przypadków DLBCL oznaczanych techniką GEP nie jest możliwe jednoznaczne przypisanie do podtypu, a algorytm opierający się na IHC nie przewiduje takiego podejścia. Tym niemniej metoda IHC jest szeroko dostępna w większości zakładów patomorfologii specjalizujących się w diagnostyce hematoonkologicznej. Dodatkowym atutem potwierdzającym zasadność utrzymania w rutynowej diagnostyce algorytmu Hansa jest jego długoletnie zastosowanie w wielu badaniach klinicznych. Niedawno opracowane testy oparte na badaniu profilu ekspresji kilkudziesięciu genów (np. Lymph2Cx NanoString lub The Archer FusionPlex Lymphoma Kit) pozwalają niezawodnie identyfikować dwa molekularne podtypy DLBCL na postawie analizy RNA wyekstrahowanego $z$ tkanek utrwalonych $\mathrm{w}$ formalinie i zatopionych w parafinie $[14,15]$. Testy te wykazują dużą zgodność $z$ wynikami opracowanymi na mikromacierzach GEP i charakteryzują się wysoką powtarzalnością. Uzyskiwane wyniki mają odzwierciedlenie w odmiennym przebiegu klinicznym dwóch podtypów DLBCL. W przyszłości najprawdopodobniej testy oparte na profilu ekspresji genów będą bardziej 
Tabela 1. Podział agresywnych chłoniaków B-komórkowych według najnowszej klasyfikacji Światowej Organizacji Zdrowia z 2017 (źródło [1])

Table 1. Division of aggressive B-cell lymphomas according to World Health Organization 2017 classification (source [1])

\begin{tabular}{|c|c|c|}
\hline Nazwa polska & Nazwa angielska & Skrót/akronim \\
\hline $\begin{array}{l}\text { Chłoniak rozlany z dużych komórek B, bliżej } \\
\text { nieokreślony } \\
\text { Typ z komórek ośrodków rozmnażania } \\
\text { Typ z aktywowanych komórek B } \\
\end{array}$ & $\begin{array}{l}\text { Diffuse large B-cell lymphoma, not otherwise } \\
\text { specified } \\
\text { Germinal center B-cell type } \\
\text { Activated B-cell type }\end{array}$ & $\begin{array}{l}\text { DLBCL, NOS } \\
\text { GCB-type } \\
\text { ABC-type }\end{array}$ \\
\hline $\begin{array}{l}\text { Chłoniak } z \text { dużych komórek B bogaty } \\
\text { w limfocyty } T / \text { histiocyty }\end{array}$ & T-cell/histiocyte-rich large B-cell lymphoma & THRLBCL \\
\hline $\begin{array}{l}\text { Chłoniaki rozlane z dużych komórek B, } \\
\text { związane z topografią } \\
\text { Pierwotny chłoniak śródpiersia (grasicy) z dużych } \\
\text { komórek B } \\
\text { Pierwotny chłoniak rozlany z dużych komórek } \\
\text { ośrodkowego układu nerwowego } \\
\text { Pierwotny skórny chłoniak rozlany z dużych } \\
\text { komórek B typu kończynowego } \\
\text { Wewnątrznaczyniowy chłoniak } \\
\text { z dużych komórek B }\end{array}$ & $\begin{array}{l}\text { DLBCL, topographic site-related } \\
\text { Primary mediastinal (thymic) large B-cell lymphoma } \\
\text { Primary DLBCL of the CNS } \\
\text { Primary cutaneous DLBCL, leg type } \\
\text { Intravascular large B-cell lymphoma }\end{array}$ & $\begin{array}{l}\text { PMBL primary } \\
\text { DLBCL, CNS } \\
\text { PCLBCL, leg type } \\
\text { IVLBCL }\end{array}$ \\
\hline $\begin{array}{l}\text { Chłoniaki rozlane z dużych komórek B, } \\
\text { związane z EBV } \\
\text { Chłoniak rozlany z dużych komórek B, bliżej } \\
\text { nieokreślony, EBV+ } \\
\text { Chłoniak rozlany z dużych komórek B związany } \\
\text { z przewlekłym zapaleniem } \\
\text { Ziarniniakowatość limfoidalna }\end{array}$ & $\begin{array}{l}\text { DLBCL, EBV-related } \\
\text { EBV-positive DLBCL, NOS } \\
\text { DLBCL associated with chronic inflammation } \\
\text { Lymphomatoid granulomatosis }\end{array}$ & $\begin{array}{l}\text { EBV+ DLBCL, NOS } \\
\text { LYG }\end{array}$ \\
\hline $\begin{array}{l}\text { Chłoniaki z dużych komórek B z końcowym } \\
\text { różnicowaniem z komórek B } \\
\text { Chłoniak plazmablastyczny } \\
\text { Chłoniak z dużych komórek B, ALK+ } \\
\text { Pierwotny chłoniak wysiękowy } \\
\text { Chłoniak rozlany z dużych komórek B, bliżej } \\
\text { nieokreślony, HHV8+* }\end{array}$ & $\begin{array}{l}\text { LBCL with terminal B-cell differentiation } \\
\text { Plasmablastic lymphoma } \\
\text { ALK-positive large B-cell lymphoma } \\
\text { Primary effusion lymphoma }\end{array}$ & $\begin{array}{l}\text { PBL } \\
\text { ALK+ LBCL } \\
\text { PEL } \\
\text { HHV8+ DLBCL, NOS }\end{array}$ \\
\hline $\begin{array}{l}\text { Chłoniak Burkitta } \\
\text { Chłoniak Burkittopodobny z aberracją 11q* }\end{array}$ & $\begin{array}{l}\text { Burkitt lymphoma } \\
\text { Burkitt-like lymphoma with 11q aberrations }\end{array}$ & BL \\
\hline $\begin{array}{l}\text { Chłoniaki o wysokim stopniu złośliwości } \\
\text { z komórek B } \\
\text { Chłoniak o wysokim stopniu złośliwości } \\
\text { z komórek B z rearanżacjami MYC i BCL2 i/lub BCL6 } \\
\text { Chłoniak o wysokim stopniu złośliwości } \\
\text { z komórek B, bliżej nieokreślony }\end{array}$ & $\begin{array}{l}\text { High-grade B-cell lymphoma } \\
\text { High-grade B-cell lymphoma, with MYC and BCL2 } \\
\text { and/or BCL6 rearrangements } \\
\text { High-grade B-cell lymphoma, NOS }\end{array}$ & $\begin{array}{l}\text { HGBL } \\
\text { HGBL, MYC-R and } \\
\text { BCL2-R and/or } \\
\text { BCL6-R } \\
\text { HGBL, NOS }\end{array}$ \\
\hline $\begin{array}{l}\text { Chłoniak z komórek płaszcza } \\
\text { Morfologiczny wariant blastoidny } \\
\text { lub pleomorficzny }\end{array}$ & $\begin{array}{l}\text { Mantle cell lymphoma } \\
\text { Blastoid or pleomorphic variant }\end{array}$ & MCL \\
\hline $\begin{array}{l}\text { Nieklasyfikowalny chłoniak z komórek B, } \\
\text { z cechami pośrednimi między chłoniakiem } \\
\text { rozlanym z komórek B a klasycznym } \\
\text { chłoniakiem Hodgkina }\end{array}$ & $\begin{array}{l}\text { B-cell lymphoma, unclassifiable, with features } \\
\text { intermediated between diffuse large B-cell } \\
\text { lymphoma and classic Hodgkin lymphoma }\end{array}$ & BCLu-DLBCL/CHL \\
\hline
\end{tabular}

*Jednostka tymczasowa

precyzyjną metodą diagnostyczną niż obecnie zaakceptowane przez WHO metody IHC.

\section{Chłoniak z dużych komórek B bogaty w komórki T/histiocyty}

Chłoniak $\mathrm{z}$ dużych komórek B bogaty w komórki T/histiocyty jest agresywnym i stosunkowo rzad- ko występującym chłoniakiem $(<10 \%$ wszystkich DLBCL). W badaniu histopatologicznym obserwuje się rozproszone, duże, atypowe komórki $\mathrm{B}$, które znajdują się $\mathrm{w}$ podścielisku zawierającym liczne limfocyty $\mathrm{T}$ i histiocyty. Chłoniak ten jest często rozpoznawany w wysokim stopniu zaawansowania klinicznego $z$ towarzyszącym zajęciem wątroby, śledziony i szpiku, co wpływa na jego agresywny 
przebieg kliniczny [16]. Wydaje się, że część przypadków THRLBCL może się rozwijać na podłożu łagodnie przebiegającego nieklasycznego chłoniaka Hodgkina guzkowego bogatego w limfocyty (NLPHL; nodular lymphocyte predominant Hodgkin lymphoma). Związek między powstającymi de novo THRLBCL a przypadkami powstającymi w wyniku transformacji nie jest do końca wyjaśniony, choć badania GEP wskazują na ich podobieństwa na poziomie molekularnym. Ze względu na podobieństwa morfologiczne i immunofenotypowe istnieją trudności w diagnostyce różnicowej między wymienionymi jednostkami $[17,18]$. Dla przypadków NLPHL zawierających rozlane pola bogate w komórki T/histiocyty przyjęto określenie THRLBCL-like transformation of NLPHL [1].

\section{Chłoniaki z dużych komórek B związane ze specyficzną lokalizacją}

W odniesieniu do niektórych chłoniaków $z$ dużych komórek B podstawą klasyfikacji jest przede wszystkim topografia zmian. Chłoniaki te mają szczególne cechy, choć nie charakteryzują się specyficznym fenotypem i zmianami molekularnymi.

Pierwotny chłoniak śródpiersia (grasicy) $z$ dużych komórek B (PMBL, primary mediastinal (thymic) large B-cell lymphoma) stanowi około $2 \%$ chłoniaków nie-Hodgkina i zazwyczaj występuje u młodych (mediana wieku 35 lat) kobiet (2 razy częściej niż u mężczyzn). Klinicznie charakteryzuje się dużym guzem ( $\mathrm{w} 60-70 \%$ przypadków średnica $>10 \mathrm{~cm}$ ) w śródpiersiu, który często może naciekać sąsiadujące struktury. Okoliczne węzły chłonne mogą być zajęte przez nacieki chłoniaka, natomiast gdy choroba rozszerza się poza klatkę piersiową, częściej stwierdza się lokalizację pozawęzłową tego chłoniaka [19]. W badaniu histopatologicznym komórki nowotworowe mają zazwyczaj obfitą, jasną cytoplazmę, a w podścielisku obserwuje się istotne włóknienie. Wydaje się, że chłoniak ten pochodzi z dojrzałych komórek B grasicy, dlatego nierzadkim zjawiskiem jest obecność pozostałości grasicy wśród nacieku chłoniaka. Komórki PMBL często wykazują ekspresję markerów PDL1/PDL2 (rearanżacja w ok. 20\% przypadków), CD30 i CD23 oraz zazwyczaj nie wykazują ekspresji IG i ludzkich antygenów leukocytarnych (HLA, human lekocyte antigen) klas I i II [20]. Pierwotny chłoniak śródpiersia ma specyficzny profil ekspresji genów, który może być przydatny w diagnostyce różnicowej PMBL i DLBCL, NOS zajmujących śródpiersie oraz w lokalizacjach poza klatką piersiową. Różnice między PMBL i DLBCL na poziomie molekularnym dotyczą między innymi rearanżacji CIITA (odpowiednio $38 \%$ v. rzadko), która prowadzi do aktywacji ścieżek sygnałowych $\mathrm{NF} \kappa \mathrm{B}$ i JAK/STAT i zmniejszenia ekspresji antygenów głównego kompleksu zgodności tkankowej klasy II [3, 21, 22].

Inne chłoniaki $z$ dużych komórek B związane ze specyficzną lokalizacją obejmują pierwotnego chłoniaka rozlanego $z$ dużych komórek ośrodkowego układu nerwowego (primary DLBCL, CNS), pierwotnego skórnego DLBCL typu kończynowego (primary cutaneous DLBCL, leg type) i wewnątrznaczyniowego chłoniaka $z$ dużych komórek $B$ (intravascular large B-cell lymphoma). Są to rzadko występujące jednostki kliniczno-patologiczne.

Pierwotny DLBCL, CNS stanowi poniżej $1 \%$ chłoniaków nie-Hodgkina i 2,4-3\% wszystkich nowotworów mózgu. Ma on odrębne cechy biologiczne związane $z$ immunologicznie uprzywilejowaną lokalizacją, w której się rozwija, między innymi brak ekspresji białek HLA klas I i II pozwala komórkom guza na uniknięcie kontroli immunologicznej. Powinien być różnicowany $z$ innymi chłoniakami $z$ dużych komórek występującymi w OUN, szczególnie związanymi z immunosupresją [23]. W chłoniaku tym często obserwuje się delecje i utratę ekspresji genów w obrębie układu HLA oraz mutacje MYD88 L265P (> 50\%), CD79B (20\%), CARD11 (16\%), które mogą mieć potencjalne znaczenie terapeutyczne [24,25]. Istnieje udowodniony związek między DLBCL, CNS a DLBCL zlokalizowanym w jądrach, ponieważ zarówno rozsiew pozaczaszkowy częściej dotyczy jąder, jak i odwrotnie - część chłoniaków jąder może się charakteryzować wznową w OUN [26].

Pierwotny skórny chłoniak rozlany z dużych komórek B typu kończynowego jest agresywnym chłoniakiem występującym w skórze kończyn dolnych (4\% pierwotnych chłoniaków skóry). Znane są również inne lokalizacje skórne. Chłoniak ten charakteryzuje się fenotypem $\mathrm{ABC}$ i silną ekspresją białek BCL2 i BCL6 [1].

Wewnątrznaczyniowy LBCL jest rzadkim i bardzo agresywnym (z wyjątkiem przypadków ograniczonych wyłącznie do skóry; 3-letnie przeżycie całkowite [OS, overall survival] $60-81 \%$ w przypadku stosowania chemioterapii $z$ dodatkiem rytuksymabu) chłoniakiem układowym, charakteryzującym się selektywnym wzrostem komórek chłoniaka w świetle naczyń krwionośnych, głównie kapilarnych [1]. 


\section{Chłoniaki z dużych komórek B związane $\mathrm{z}$ infekcją EBV}

Grupa chłoniaków $z$ dużych komórek B związanych $z$ infekcją EBV charakteryzuje się odmiennym od DLBCL, NOS obrazem klinicznym i cechami patomorfologicznymi. Chłoniaki te występują u chorych $z$ pozornie prawidłową odpowiedzią immunologiczną. Najczęściej występującym chłoniakiem $z$ tej grupy jest chłoniak rozlany $z$ dużych komórek B, bliżej nieokreślony, EBV + (DLBCL EBV +, NOS). Określenie „bliżej nieokreślony” oznacza, że istnieją inne chłoniaki z dużych komórek B EBV+, które mają odrębne cechy kliniczne i histopatologiczne. W poprzedniej klasyfikacji WHO z 2008 roku jednostkę tę nazywano chłoniakiem rozlanym $z$ dużych komórek B EBV+ osób starszych $z$ powodu znamiennie częstszego występowania tego chłoniaka u chorych powyżej 50 . roku życia (ze szczytem zachorowań przypadającym na 8. dekadę życia) [27]. Jednak w ostatnich badaniach wykazano, że chłoniaki te mogą występować również u młodszych chorych (głównie w 3 . dekadzie życia i niemal 3 razy częściej u mężczyzn) [1,2]. W badaniu histopatologicznym widoczne są duże atypowe komórki B, które mogą przypominać komórki Hodgkina i Reed-Sternberga oraz obserwuje się odczyn zapalny podścieliska o zmiennym nasileniu z udziałem cytotoksycznych limfocytów T (CD8+), plazmocytów i histiocytów. Ponadto w większości przypadków obecne są pola martwicy nowotworowej. Cechy histopatologiczne mogą sugerować rozpoznanie, ale powinno być ono każdorazowo potwierdzone w badaniu w kierunku obecności EBV metodą hybrydyzacji wewnątrztkankowej (ISH, in situ hybridization), która jest nadrzędną metodą w stosunku do barwień IHC. Wirus Epstein-Barr występuje w większości komórek chłoniaka i zazwyczaj jest w II i III fazie latencji [28]. Rokowanie jest znacząco bardziej niekorzystne u pacjentów starszych niż u młodszych. Inne chłoniaki z dużych komórek związane $z$ infekcją EBV obejmują chłoniaka rozlanego $z$ dużych komórek B związanego $z$ przewlekłym zapaleniem (DLBCL associated with chronic inflammation) oraz ziarniniakowatość limfoidalną (LyG, lymphomatoid granulomatosis). Pierwszy $z$ chłoniaków występuje w przebiegu długo trwającego zapalenia zlokalizowanego w ograniczonych jamach i szczelinach ciała, takich jak opłucna (pyothorax), kości lub stawy. Ziarniniakowatość limfoidalną stwierdza się w okolicach pozawęzłowych, najczęściej w płucach. Cechą charakterystyczną LyG w badaniu histopatologicznym jest naciekanie naczyń przez komórki nowotworo- we (wzmożony angiocentryzm) oraz ich niszczenie (angiodestrukcja). Chłoniaki te są zbudowane $z$ różnorodnej liczby dużych atypowych komórek B wykazujących ekspresję EBV współwystępujących z odczynowymi limfocytami T. Ponadto wykazuje on całe spektrum histopatologicznej i klinicznej złośliwości, co zależy od liczby dużych komórek B $\mathrm{EBV}+[1,2]$.

\section{Chłoniaki z dużych komórek B z końcowym różnicowaniem komórek B}

Chłoniaki z dużych komórek B z końcowym różnicowaniem komórek B (LBCL with terminal $B$-cell differentiation) obejmują heterogenną grupę agresywnych chłoniaków, które charakteryzują się immunoblastyczną lub plazmablastyczną morfologią komórek, fenotypem komórek plazmatycznych $z$ brakiem lub zmniejszeniem ekspresji markerów komórek B (CD20 i PAX5) oraz ekspresją antygenów komórek plazmatycznych (CD38, CD138, IRF4/MUM1 i PRDM1/BLIMP1) [1].

Chłoniak plazmablastyczny (PBL, plasmablastic lymphoma) rozwija się u chorych ze stanami obniżonej odporności, wywołanymi głównie zakażeniem ludzkim wirusem nabytego niedoboru odporności (HIV, human immunodeficiency virus), jak również podczas jatrogennej immunosupresji (po transplantacjach, chorobach autoimmunologicznych). Jest zlokalizowany głównie pozawęzłowo, najczęściej w obrębie głowy i szyi, w tym w jamie ustnej, także w przewodzie pokarmowym, ale choroba jest zazwyczaj ( $>75 \%$ pacjentów $z$ infekcją HIV) w fazie uogólnienia już w momencie rozpoznania [29-31]. W części przypadków PBL zajmuje kości i wtedy ma cechy morfologiczne i immunofenotypowe nakładające się $z$ cechami szpiczaka plazmocytowego. W diagnostyce różnicowej należy wziąć pod uwage obraz kliniczny PBL oraz niedobory odporności i zakażenie EBV. Epstein-Barr wirus w I fazie latencji jest obecny w około $70 \%$ przypadków. Translokacja $M Y C$ występuje u około $50 \%$ chorych, zwykle $z$ partnerem $I G$ [32]. Przebieg kliniczny jest bardzo agresywny ze średnią przeżycia od 6 do 11 miesięcy.

Zakażenie HHV8 wywołuje spektrum chorób limfoproliferacyjnych (HHV8+ wieloogniskowa choroba Castelmana, germinotropic lymphoproliferative disorder) $\mathrm{z}$ dwoma podtypami chłoniaków — pierwotnym chłoniakiem wysiękowym (PEL, primary effusion lymphoma) i chłoniakiem rozlanym z dużych komórek B, bliżej nieokreślonym, HHV8+ (HHV8+ DLBCL, NOS) [33]. Pierwotny chłoniak wysiękowy występuje głównie w jednej $z$ jam ciała 
(jama opłucnej, osierdzia i otrzewnej), bez masy węzłowej. W przebiegu PEL u niektórych pacjentów może się rozwinąć guz o podobnych cechach patomorfologicznych (najczęściej w przewodzie pokarmowym, skórze, płucach, OUN lub węzłach chłonnych); rzadkie przypadki od początku występują w postaci guza i są określane jako extracavitary PEL. W większości przypadków EBV występuje w I fazie latencji, choć u niektórych chorych, głównie u starszych, bez towarzyszącej infekcji HIV i w miejscach endemicznego występowania HHV8 (basen Morza Śródziemnego) nie można wykazać ekspresji wirusa. Chłoniak HHV8+ DLBCL, NOS ma podobną morfologię i fenotyp, ale nie obserwuje się infekcji EBV. Ponadto chłoniak ten jest monoklonalny, wykazuje ekspresję IgM lambda i charakteryzuje się niezmutowanym IGHV. Najczęściej rozwija się on na podłożu wieloogniskowej choroby Castlemana HHV8 + w przebiegu infekcji HIV (15 razy częściej niż bez choroby Castlemana HHV8+) [1, 33].

Chłoniak z dużych komórek B, ALK+ (ALK+ LBCL, ALK-positive large B-cell lymphoma) jest bardzo agresywnym chłoniakiem (całkowite przeżycie w stadium III/IV wynosi zaledwie 11 miesięcy) występującym u młodych mężczyzn (mediana wieku to 43 lata, 5 razy częściej niż u kobiet) bez zaburzeń odporności. Jedna trzecia zachorowań występuje u dzieci i wówczas czasy przeżycia są nieco dłuższe. Klinicznie u chorych stwierdza się uogólnioną limfadenopatię i wysoki stopień zaawansowania klinicznego. Plazmablastyczny fenotyp tego chłoniaka wydaje się indukowany przez aktywację kinazy ALK z powodu translokacji, głównie $A L K-C L T C$ (t $(2 ; 17)(\mathrm{p} 23 ; \mathrm{q} 23))$, choć znane są także inne fuzyjne geny partnerskie. Produkt białkowy rearanżacji genu $A L K$ wydaje się aktywować ścieżkę sygnałową STAT3. Jest to potencjalnie istotny punkt uchwytu dla terapii celowanej w przyszłości [34-36].

\section{Chłoniak Burkitta}

Chłoniak Burkitta (BL, Burkitt lymphoma) jest dobrze zdefiniowanym chłoniakiem, który genetycznie charakteryzuje się rearanżacją genu MYC (lokalizacja 8q24), prowadzącą do przeniesienia części kodującej genu $\mathrm{w}$ region promotora jednego $z$ genów immunoglobulin (IGH/14q32 lub IGL/22q11 lub IGK/2p12) i prostym kariotypem $[37,38]$. W ostatnich latach, dzięki przeprowadzonym badaniom pogłębionego sekwencjonowania (NGS, next-generation sequencing), określono profil mutacji somatycznych $z$ częstymi mutacjami ( $70 \%$
BL sporadycznych) w genach regulujących ścieżkę PI3K obejmujących czynnik transkrypcyjny TCF3 (E2A) i jego negatywny regulator ID3, które bardzo rzadko występują w DLBCL. U $30 \%$ chorych na BL wykryto również mutację CCND3 [39]. W około $10 \%$ klasycznych BL nie udaje się wykryć rearanżacji $M Y C$. Wydaje się, że istnieje co najmniej kilka mechanizmów alternatywnego aktywowania $M Y C$ (m.in. mikroRNA, amplifikacja, transkrypcyjne zwiększenie aktywności) [40, 41]. W badaniach $z$ ostatnich lat opisano przypadki o podobnej do BL morfologii i fenotypie, ale bez rearanżacji $M Y C$, które mają nieprawidłowości w obrębie chromosomu 11q wykrywane na poziomie kariotypu. Dla tych przypadków w klasyfikacji WHO z 2017 roku utworzono tymczasową jednostkę ,,chłoniak burkittopodobny z aberracją 11q" (Burkitt-like lymphoma with $11 q$ aberration). Dotychczas opublikowano nieliczne opisy przypadków tej choroby, w których między innymi zaobserwowano częstszą niż w klasycznym BL prezentację węzłową, większy pleomorfizm komórkowy, złożony kariotyp i niższy poziom ekspresji białka MYC [42, 43]. Przebieg kliniczny wydaje się podobny do występującego w klasycznym BL [44].

\section{Chłoniaki o wysokim stopniu złośliwości z komórek B}

Chłoniak o wysokim stopniu złośliwości z komórek B (HGBL, high-grade B-cell lymphoma) jest nową jednostką w zaktualizowanej klasyfikacji WHO z 2017 roku, która obejmuje grupę chłoniaków o bardzo agresywnym przebiegu klinicznym (mediana przeżycia oscyluje od 4,5 do 18,5 miesięcy) $[1,2]$. $Z$ definicji, w celu właściwego ustalenia rozpoznania w tej grupie chłoniaków, konieczne jest wykonanie badań genetycznych. Ze względu na niejednoznaczne kryteria diagnostyczne w poprzedniej klasyfikacji WHO z 2008 roku HGBL zastąpił dotychczas rozpoznawanego chłoniaka z komórek B, nieklasyfikowalnego, $z$ cechami pośrednimi między chłoniakiem rozlanym $z$ dużych komórek $\mathrm{B}$ a chłoniakiem Burkitta (BCLU, DLBCL/BL, B-cell lymphoma, unclassifiable, with features intermediate between diffuse large $B$-cell lymphoma and Burkitt lymphoma). Wyniki badań genetycznych określiły, że $32-78 \%$ chłoniaków tej kategorii cechuje rearanżacja $M Y C i B C L 2$ i/lub $B C L 6$, dlatego w ramach HGBL zdefiniowano nową jednostkę - chłoniaka $z$ komórek $\mathrm{B}$ o wysokiej złośliwości z rearanżacją $M Y C$ i BCL2 i/lub BCL6 (high-grade B-cell lymphoma, with MYC and BCL2 and/or BCL6 rearrangements) [45-49]. 
Przypadki te są té̇ nazywane „double/triple hit” HGBL (HGBL-DH/TH) i $z$ definicji obejmują, odpowiednio, następujące opcje rearanżacji $M Y C$ i $B C L 2, M Y C$ i $B C L 6$ (o lepszym rokowaniu) oraz $M Y C, B C L 2$ i $B C L 6$. Istotnymi kryteriami dla rozpoznania ,double/triple hit” HGBL są zmiany genetyczne niezależnie od morfologii HGBL, która może być blastoidna, o cechach pośrednich między DLBCL i BL lub przypominać DLBCL. Specyficzna morfologia powinna być odnotowana w raporcie histopatologicznym, ponieważ może mieć znaczenie rokownicze [48]. Przypadki o blastoidnej morfologii lub o morfologii DLBCL/BL bez wspomnianych wyżej rearanżacji należy klasyfikować jako chłoniaki o wysokim stopniu złośliwości z komórek B, bliżej nieokreślone (high-grade B-cell lymphoma, NOS). Przypadki $z$ wysoką ekspresją białek MYC (w $>40 \%$ jąder komórkowych) i BCL2 ( $w>50 \%$ komórek chłoniaka) bez jednoczesnych zmian genetycznych (rearanżacji $M Y C$ i $B C L 2$ ) określane są jako DLBCL double-expressors (DE) lymphoma (DE-DLBCL) [1]. Ekspresję białek MYC i BCL2 wykazano w 19-34\% przypadków DLBCL i uznano za niekorzystny czynnik prognostyczny DE-DLBCL nie włączono do kategorii HGBL, ponieważ wydaje się, że rokowanie nie jest tak niekorzystne jak w HGBL, a konsekwencje biologiczne zmian genetycznych mogą być również inne [48]. Ciekawy jest również fakt, że DE-DLBCL należą głównie do podtypu $\mathrm{ABC}$, natomiast HGBL-DH wykazują pochodzenie GCB. Oznaczanie rearanżacji $M Y C$ i $B C L 2$ i/lub BCL6 metodą fluorescencyjnej hybrydyzacji wewnątrztkankowej (FISH, fluorescence in situ hybridization) u chorych na chłoniaki agresywne wykazało, że kliniczne znaczenie zmian genetycznych jest bardziej zróżnicowane niż to sugerowano w początkowych badaniach, ponieważ nie wszystkie tego typu chłoniaki charakteryzują się agresywnym przebiegiem klinicznym [50]. Przyczyny tego zjawiska nie są jeszcze poznane, ponieważ patogeneza HGBL-DH jest złożona i pozostaje nie do końca zrozumiała. Obecność rearanżacji $M Y C$ w HGBL jest niekorzystnym czynnikiem prognostycznym, lecz wydaje się, że jego biologiczne znaczenie ulega wieloczynnikowej modulacji. Jednoczesne występowanie rearanżacji $M Y C$ i $B C L 2$ zazwyczaj jest przyczyną niekorzystnego rokowania, natomiast rokownicza rola rearanżacji $B C L 6$ wciąż jest dyskusyjna [50, 51]. Znaczenie ma również typ genu partnerskiego translokacji $M Y C ; I G-M Y C$ wiąże się $z$ silniejszą ekspresją MYC niż w przypadku non-IG-MYC, co może tłumaczyć gorsze rokowanie w pierwszym przypadku. W przypadkach rearanżacji $M Y C$ na poziom jego ekspresji na poziomie białka mogą wpływać inne, dodatkowe czynniki, takie jak amplifikacja alleli biorących udział w translokacji, mutacje $M Y C$ lub inne [3, 50].

Morfologia komórek chłoniaków może mieć również wpływ na rokowanie; rokowanie w przypadkach o morfologii DLBCL $z$ rearanżacją $M Y C$ jest lepsze niż w przypadkach o morfologii blastoidnej lub o cechach pośrednich między DLBCL i BL. Ważny jest również obraz kliniczny — chorzy obciążeni niekorzystnymi czynnikami rokowniczymi na poziomie klinicznym rokują gorzej niż pacjenci cechujący się niskim ryzykiem. Wydaje się, że do lepszego zrozumienia znaczenia tej nowej kategorii chłoniaków potrzebne są dalsze badania służące ocenie wszystkich powyższych parametrów. Niezależnie od wszystkich tych zmiennych rozpoznanie HGBL-DH jest klinicznie istotne, ponieważ większość $z$ nich ma bardzo agresywny przebieg, W związku $z$ czym standardowe leczenie zalecane w DLBCL uważa się za niewystarczające [1]. Konieczność rozpoznawania HGBL-DH stanowi wyzwanie w diagnostyce różnicowej agresywnych chłoniaków $z$ komórek B, ponieważ stosowanie badań FISH we wszystkich przypadkach może powodować trudności związane $z$ większym obciążaniem pracą i problemy finansowe w większości ośrodków zajmujących się tą diagnostyką. Wytyczne, w których określono zasady wykonywania badań FISH $\mathrm{u}$ chorych na agresywne chłoniaki $\mathrm{z}$ komórek $\mathrm{B}$, pozostają kontrowersyjne, a selektywny wybór przypadków do analizy FISH na podstawie morfologii i fenotypu pozostawia wiele do życzenia. Praktycznie wszystkie HGBL-DH z translokacją $M Y C$ i $B C L 2$ należą do podtypu GCB, a przypadki $z$ rearanżacjami cechuje zazwyczaj wysoka ekspresja tych białek. Teoretycznie rozsądną strategią byłoby wykonywanie FISH we wszystkich DLBCL GCB $Z$ wysoką ekspresją białek MYC i BCL2. Ponadto badania tą metodą powinny być wykonywane w przypadkach agresywnych chłoniaków z komórek $\mathrm{B}$ o morfologii blastoidnej lub pośredniej między DLBCL i BL ze względu na dużą częstość translokacji (ok. 50\%) w tych nowotworach [52]. Podsumowując, preselekcja przypadków ze względu na morfologię lub ekspresję BCL2 i MYC albo stwierdzenie wysokiego wskaźnika proliferacyjnego (Ki-67 > 90\%) może spowodować pominięcie niektórych HGBL-DH z rearanżacjami $B C L 6$ o fenotypie DLBCL ABC i HGBL-DH o niskiej ekspresji białek, dlatego według rekomendacji WHO z 2017 roku optymalne wydaje się badanie wszystkich przypadków $[1,2]$. Na rycinach 1-3 przedstawiono kompleksową diagnostykę 

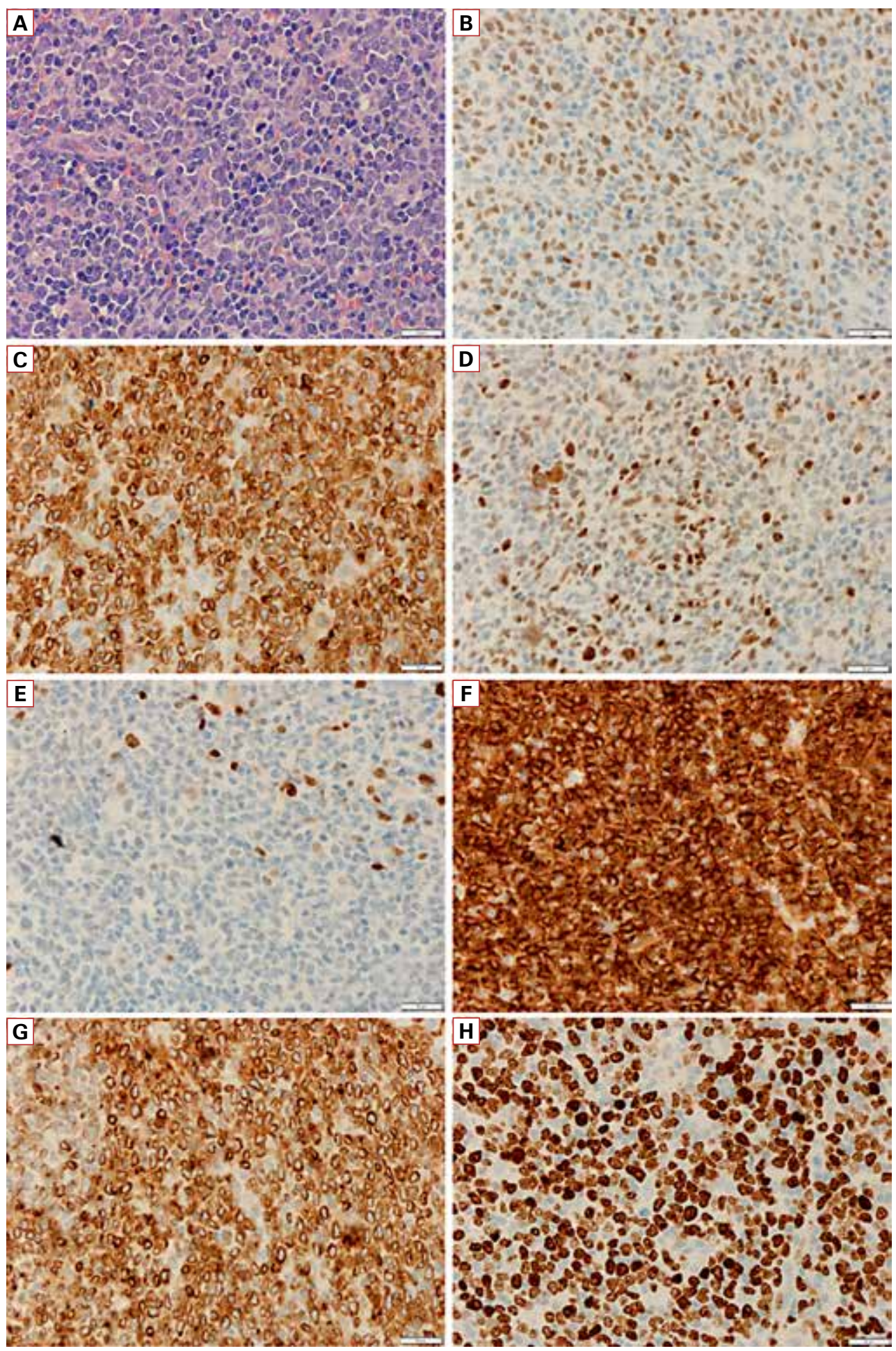

Rycina 1A-H. Diagnostyka różnicowa chłoniaków o wysokim stopniu złośliwości z komórek $B$ techniką immunohistochemiczną; materiał - węzeł chłonny; zastosowane barwienia: hematoksyliną i eozyną, powiększenie $40 \times(A)$; C-MYC, powiększenie $40 \times(B)$; BCL2, powiększenie $40 \times(\mathbf{C})$; BCL6, powiększenie $40 \times($ D); MUM1, powiększenie $40 \times(\mathbf{E})$; CD20, powiększenie $40 \times(\mathbf{F})$; CD10, powiększenie $40 \times(\mathbf{G})$; Ki-67, powiększenie $40 \times(\mathbf{H})$. Ostateczne rozpoznanie: chłoniak o wysokim stopniu złośliwości z komórek B z rearanżacjami $M Y C$ i $B C L 6$, o podwójnej ekspresji

Figure 1A-H. Differential diagnosis of high-grade B-ell lymphomas using immunohistochemical technique; material: lymph node; applied staining: hematoxylin and eosin, magnification of $40 \times(\mathrm{A})$; C-MYC, magnification of $40 \times(B)$; $\mathrm{BCL} 2$, magnification of $40 \times(\mathbf{C})$; BCL6, magnification of $40 \times(\mathbf{D})$; MUM1, magnification of $40 \times(\mathbf{E})$; CD20, magnification of $40 \times(\mathbf{F})$; CD10, magnification of $40 \times(\mathbf{G})$. Final diagnosis: high-grade B-cell lymphoma, with $M Y C$ and $B C L 6$ rearrangements, double expressor 

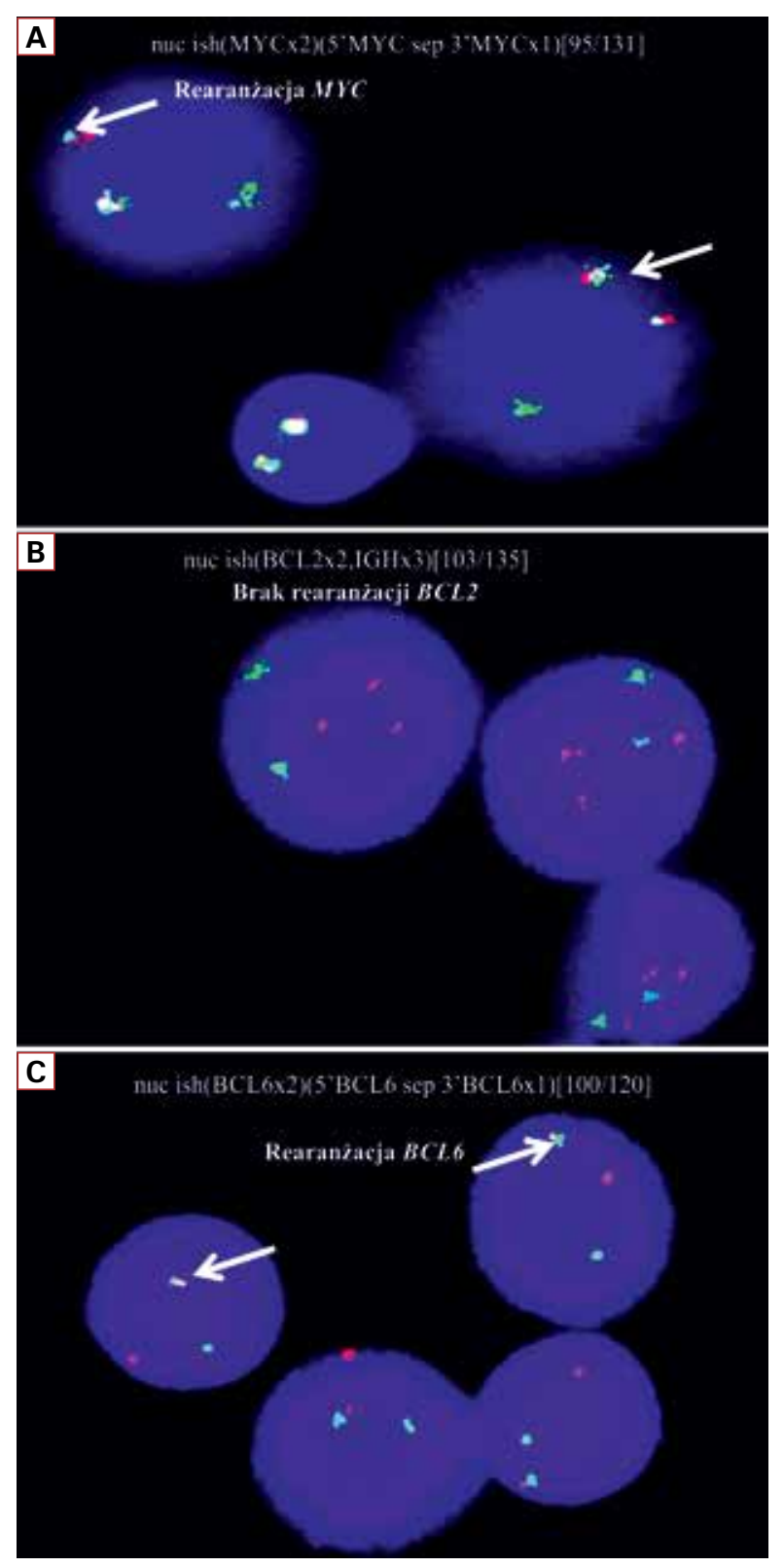

Rycina 2A-C. Diagnostyka różnicowa chłoniaków o wysokim stopniu złośliwości z komórek B techniką fluorescencyjnej hybrydyzacji wewnątrztkankowej; materiał - szpik kostny; zastosowane sondy molekularne: ON MYC (8q24) Triple Color, Break, Kreatech (A); ONBCL2/ /IGH t $(14 ; 18)$ Fusion, Kreatech (B); ON BCL6 (3q27) Break, Kreatech (C). Zdjęcia dzięki uprzejmości dr n. med. Katarzyny Borg

Figure 2A-C. Differential diagnosis of high-grade lymphomas from B-cells by fluorescence in situ hybridization; material: bone marrow; molecular probes used: ON MYC (8q24) Triple Color, Break, Kreatech (A); ON $\mathrm{BCL2/IGH} \mathrm{t(14;} \mathrm{18)} \mathrm{Fusion,} \mathrm{Kreatech} \mathrm{(B);} \mathrm{ON} \mathrm{BCL6}$ (3q27) Break, Kreatech (C). Photos thanks to Dr. Katarzyna Borg agresywnych chłoniaków B-komórkowych uwzględniającą również badania molekularne.

\section{Nieklasyfikowalny chłoniak z komórek B, $z$ cechami pośrednimi między chłoniakiem rozlanym $\mathrm{z}$ komórek $\mathrm{B}$ a klasycznym chłoniakiem Hodgkina}

W aktualnej klasyfikacji WHO, choć miała to być jednostka tymczasowa, utrzymano rozpoznanie nieklasyfikowalnego chłoniaka $z$ komórek $B$, $z$ cechami pośrednimi między chłoniakiem rozlanym $\mathrm{z}$ komórek $\mathrm{B}$ a klasycznym chłoniakiem Hodgkina (BCLu-DLBCL/cHL, B-cell lymphoma, unclassifiable, with features intermediated between diffuse large B-cell lymphoma and classic Hodgkin lymphoma). Najczęściej występuje on u młodych mężczyzn, między 20. a 40. rokiem życia, i zwykle rozwija się w postaci guza śródpiersia przedniego, dlatego często określa się go mianem chłoniaka szarej strefy śródpiersia (MGZL, mediastinal grey-zone lymphoma). U osób starszych zdarza się także pierwotne zajęcie węzłów chłonnych poza śródpiersiem, wątrobą, śledzioną czy szpikiem kostnym i wtedy potocznie nazywa się go chłoniakiem szarej strefy (GZL, grey-zone lymphoma) [53]. Każdorazowo chłoniak ten wymaga różnicowania między cHL i DLBCL, zwłaszcza PMBL, $z$ którym ma najprawdopodobniej najbliższy związek w zakresie etiologii, cech morfologicznych i molekularnych. Mikroskopowo chłoniak ten cechuje się dużą komórkowością, często $z$ widocznymi litymi obszarami pleomorficznych komórek $z$ rozproszonym włókniejącym podścieliskiem w tle. W tym samym guzie zazwyczaj stwierdza się obszary przypominające cHL, fragmenty o fenotypie bliższym PMBL oraz morfologicznie formy pośrednie między wyżej wymienionymi i DLBCL. Zwykle występują niewielki naciek zapalny, ogniskowo widoczne eozynofile, limfocyty i histiocyty. Martwica występuje często, ale w przeciwieństwie do cHL nie obserwuje się towarzyszących nacieków granulocytarnych [54]. Przypadki o morfologii zbliżonej do cHL wykazują silną ekspresję CD20 i CD79a, zwykle CD30, i mogą wykazywać ekspresję CD15, natomiast te morfologicznie bardziej podobne do PMBL tracą ekspresję markerów B-komórkowych (CD20, CD79a) przy utrzymaniu ekspresji CD30 i CD15. Ponadto w BCLu-DLBCL/cHL zwykle widoczny jest dodatni odczyn $z \mathrm{CD} 45$ i czynnikami transkrypcyjnymi PAX5, OCT2 i BOB1, ekspresja BCL6 określana jest jako zmienna, a odczyny CD10 


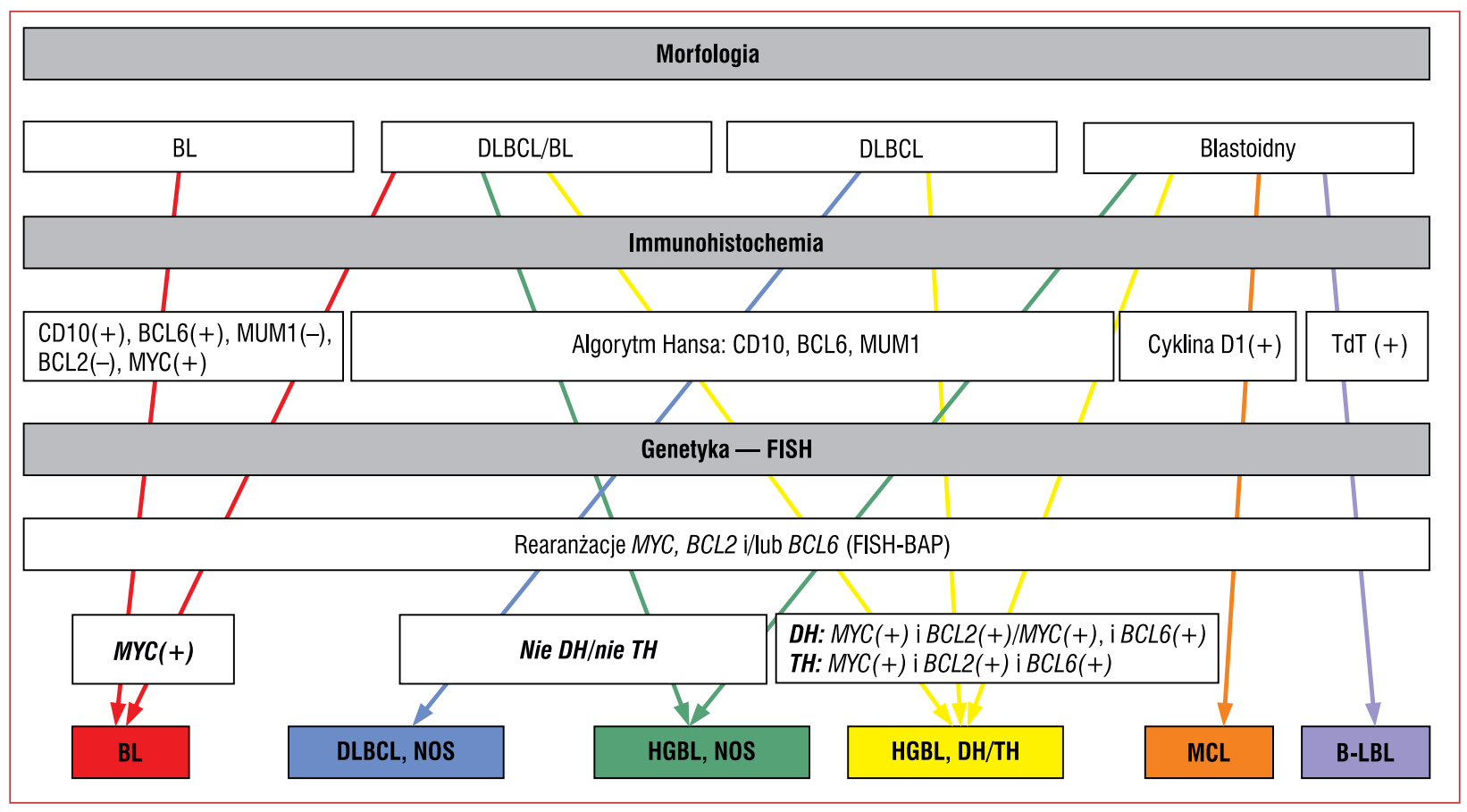

Rycina 3. Algorytm diagnostyczny dla agresywnych chłoniaków B-komórkowych; BL — chłoniak Burkitta; DLBCL — chłoniak rozlany z dużych komórek B; TdT — terminalna dezoksynukleotydylowa transferaza wewnątrzjądrowa; FISH - fluorescencyjna hybrydyzacja wewnątrztkankowa; FISH-BAP - break apart FISH; DH — "double hit"; $\mathrm{TH}$ — "triple hit"; DLBCL, NOS — chłoniak rozlany z dużych komórek B, bliżej nieokreślony; HGBL, NOS — chłoniak o wysokim stopniu złośliwości z komórek B, bliżej nieokreślony; MCL — chłoniak z komórek płaszcza; B-LBL — chłoniak limfoblastyczny B-komórkowy

Figure 3. Diagnostic algorithm for agressive B-cell lymphomas; BL - Burkitt lymphoma; DLBCL — diffuse large B-cell lymphoma; TdT - terminal deoxynucleotidyl transferase; FISH - fluorescence in situ hybridization; FISH-BAP — break-apart FISH probe; DH — "double hit"; TH — "triple hit"; DLBCL, NOS — diffuse large B-cell lymphoma, not otherwise specified; HGBL, NOS — high-grade B-cell lymphoma, not otherwise specified; MCL — mantle cell lymphoma; B-LBL — B-cell lymphoblastic leukemia/lymphoma

i ALK są negatywne. Przypadki o słabej ekspresji CD20 i cechach wskazujących na cHL nie powinny być rozpoznawane jako BCLu-DLBCL/cHL. Należy również pamiętać, że niektóre podtypy DLBCL (np. PMBL) mogą wykazywać ekspresję CD30, co nie powinno decydować o rozpoznaniu MGZL [1]. Większość przypadków BCLu-DLBCL/ /cHL jest EBV-negatywna; wykazanie EBER lub LMP1 powinno nasuwać podejrzenie DLBCL $\mathrm{EBV}+$, zwłaszcza $\mathrm{w}$ grupie starszych pacjentów [55]. Synchronicznego ani metachromatycznego wspólistnienia cHL i PMBL obecnie nie uznaje się za tożsame $z$ MGZL. $Z$ kolei BCLu-DLBCL/ /cHL wykazuje wiele podobieństw genetycznych do PBML, do których zalicza się między innymi amplifikację JAK2 i PDL2 dotyczącą ponad połowy przypadków, zwiększoną ekspresję ligandu programowanej śmierci komórki 1 (PD-L1, programmed-death ligand 1), jądrowe występowanie białka c-REL/p65 i częstszą amplifikację 2q16.1 obejmującą gen $R E L[56,57]$. Ponadto rozdzielenie sygnałów w obrębie locus CIITA (16p13.13) stwierdza się w około $1 / 3$ przypadków, podobnie amplifikacje MYC obserwuje się w 20-30\%. Powyższe zmiany genetyczne dotyczą zarówno w MGZL jak i GZL; jednym $z$ wyjątków jest znamiennie częstsza amplifikacja 9q24.1 w MGZL w stosunku do GZL (odpowiednio 61\% v. 38\%) [58]. Schematy leczenia stosowane $\mathrm{w} \mathrm{cHL}$, takie jak ABVD (doksorubicyna, bleomycyna, winblastyna, dakarbazyna), są mniej skuteczne niż wykorzystywane w leczeniu DLBCL. Podobnie jak w przebiegu cHL również $\mathrm{w}$ tym przypadku obniżenie liczby limfocytów wiąże się $z$ gorszym rokowaniem [59]. W jednym $z$ opublikowanych badań zwiększenie liczby komórek dendrytycznych (DC-SIGN-pozytywne komórki dendrytyczne) wiązało się z gorszym rokowaniem, podobnie do pogarszającej rokowanie w cHL zwiększonej liczby makrofagów [60, 61]. 


\section{Chłoniak z komórek płaszcza}

Chłoniak z komórek płaszcza (MCL, mantle cell lymphoma) jest agresywnym chłoniakiem zbudowanym $z$ monomorficznych małych lub średnich komórek limfoidalnych $z$ nieregularnym obrysem jądra komórkowego. Stanowi on 3-10\% chłoniaków nie-Hodgkina i niemal 2-krotnie częściej występuje u mężczyzn $z$ medianą wieku zachorowania około 60 lat [62]. Najczęstszą lokalizacją MCL są węzły chłonne. Często zajęte są także śledziona i szpik kostny; pozawęzłowo jest spotykany w obrębie pierścienia Waldeyera, płuc, opłucnej oraz przewodu pokarmowego. U większości chorych w chwili rozpoznania stwierdza się III lub IV stopień klinicznego zaawansowania choroby $z$ towarzyszącymi limfadenopatią, hepatosplenomegalią i zajęciem szpiku kostnego [63].

Klasyczny MCL prezentuje się jako monomorficzny rozrost limfoidalny zbudowany $z$ jednorodnych małych lub średnich komórek $\mathrm{z}$ nieregularnym jądrem. Komórki nowotworowe mogą przypominać centroblasty, immunoblasty lub paraimmunoblasty, a centra rozmnażania są zazwyczaj niewidoczne. Do rzadkich wariantów morfologicznych, charakteryzujących się wybitnie agresywnym przebiegiem, zalicza się MCL o fenotypie blastoidnym i pleomorficznym $[1,13]$.

Chłoniak $z$ komórek płaszcza charakteryzuje ekspresja CD5, BCL2, FMC7, CD43, LEF1 (częściej dodatni w wariancie blastoidnym lub pleomorficznym) i CD200 (stwierdzany w wariancie białaczkowym, pozawęzłowym) oraz negatywny odczyn z BCL6 i CD10. Dla rozpoznania kluczowe jest wykazanie obecności cykliny D1 ( $\mathrm{w}>95 \%$ przypadków, efekt translokacji $(11,14)(q 13 ; q 32)$ między genami $I G H$ i CCND1), zwłaszcza w przypadkach CD5-negatywnych [64]. Pomocniczo stwierdza się dodatni odczyn SOX11 wykrywany w ponad $90 \%$ przypadków [65]. W rzadkich przypadkach bez ekspresji cykliny D1 alternatywnie obecna jest wysoka ekspresja cyklin D2 i D3 [66].

Do zaktualizowanych niekorzystnych czynników rokowniczych należą przede wszystkim wysoki wskaźnik mitotyczny (> 10-37,5 mitoz/15 dużych pól widzenia lub $>50 \mathrm{mitoz} / \mathrm{mm}^{2}$ ) i wysoki wskaźnik Ki-67 (aktualnie punkt odcięcia wynosi $>30 \%$ ) [67]. Rokowanie pogarszają także morfologia blastoidna lub pleomorficzna, złożony kariotyp, mutacja/nadekspresja/utrata w obrębie TP53, delecja CDKN2A i wiele innych czynników klinicznych $[68,69]$. Mediana przeżycia całkowitego w MCL wynosi 3-5 lat i, niestety, mimo zastosowania najnowszych terapii nie udaje się wyleczyć większości chorych [63].

\section{Finansowanie}

Praca została zrealizowana $z$ wykorzystaniem infrastruktury projektu nr POIG.02.03.00-14-111/13 sfinansowanego z Programu Operacyjnego Innowacyjna Gospodarka 2007-2013, Priorytet II. Infrastruktura strefy $\mathrm{B}+\mathrm{R}$, Działanie 2.3. Inwestycje związane $z$ rozwojem infrastruktury informatycznej nauki.

\section{Piśmiennictwo}

1. Swerdlow SH, Campo E, Harris NL, et al. WHO Classification of Tumours of Haematopoietic and Lymphoid Tissues (Revised $4^{\text {th }}$ edition). IARC, Lyon. 2017.

2. Swerdlow SH, Campo E, Pileri SA, et al. The 2016 revision of the World Health Organization classification of lymphoid neoplasms. Blood. 2016; 127(20): 2375-2390, doi: 10.1182/ /blood-2016-01-643569, indexed in Pubmed: 26980727.

3. Taylor J, Xiao W, Abdel-Wahab O. Diagnosis and classification of hematologic malignancies on the basis of genetics. Blood. 2017; 130(4): 410-423, doi: 10.1182/blood-2017-02-734541, indexed in Pubmed: 28600336.

4. Johnsen HE, Bergkvist KS, Schmitz A, et al. Myeloma Stem Cell Network (MSCNET). Cell of origin associated classification of B-cell malignancies by gene signatures of the normal B-cell hierarchy. Leuk Lymphoma. 2014; 55(6): 1251-1260, doi: 10.3109/1 0428194.2013.839785, indexed in Pubmed: 23998255.

5. Li S, Young KH, Medeiros LJ. Diffuse large B-cell lymphoma. Pathology. 2018; 50(1): 74-87, doi: 10.1016/j.pathol.2017.09.006, indexed in Pubmed: 29167021.

6. Ott G. Aggressive B-cell lymphomas in the update of the $4^{\text {th }}$ edition of the World Health Organization classification of haematopoietic and lymphatic tissues: refinements of the classification, new entities and genetic findings. Br J Haematol. 2017; 178(6): 871-887, doi: 10.1111/bjh.14744, indexed in Pubmed: 28748558.

7. Roschewski M, Staudt LM, Wilson WH. Diffuse large B-cell lymphoma-treatment approaches in the molecular era. Nat Rev Clin Oncol. 2014; 11(1): 12-23, doi: 10.1038/nrclinonc.2013.197, indexed in Pubmed: 24217204.

8. Pasqualucci L, Dalla-Favera R. The genetic landscape of diffuse large B-cell lymphoma. Semin Hematol. 2015; 52(2): 67-76, doi: 10.1053/j.seminhematol.2015.01.005, indexed in Pubmed: 25805586.

9. Schneider C, Pasqualucci L, Dalla-Favera R. Molecular pathogenesis of diffuse large B-cell lymphoma. Semin Diagn Pathol. 2011; 28(2): 167-177, indexed in Pubmed: 21842702.

10. Camicia R, Winkler HC, Hassa PO. Novel drug targets for personalized precision medicine in relapsed/refractory diffuse large B-cell lymphoma: a comprehensive review. Mol Cancer. 2015; 14: 207, doi: 10.1186/s12943-015-0474-2, indexed in Pubmed: 26654227.

11. Chiappella A, Santambrogio E, Castellino A, et al. Integrating novel drugs to chemoimmunotherapy in diffuse large B-cell lymphoma. Expert Rev Hematol. 2017; 10(8): 697-705, doi: 10.1080/ /17474086.2017.1350164, indexed in Pubmed: 28665232.

12. Warzocha K. Leczenie chorych na chłoniaki rozlane $z$ dużych komórek B. Acta Haematol Pol. 2015; 46: 47, doi: 10.1016/j.achaem. 2015.07.342. 
13. Klapper W. Histopathology of mantle cell lymphoma. Semin Hematol. 2011; 48(3): 148-154, doi: 10.1053/j.seminhematol.2011.03.006, indexed in Pubmed: 21782056.

14. Altenbuchinger M, Schwarzfischer P, Rehberg T, et al. Molecular signatures that can be transferred across different omics platforms. Bioinformatics. 2017; 33(14): i333-i340, doi: 10.1093/bioinformatics/btx241, indexed in Pubmed: 28881975.

15. Yoon N, Ahn S, Yong Yoo H, et al. Cell-of-origin of diffuse large B-cell lymphomas determined by the Lymph2Cx assay: better prognostic indicator than Hans algorithm. Oncotarget. 2017; 8(13): 22014-22022, doi: 10.18632/oncotarget.15782, indexed in Pubmed: 28423544.

16. Cheng CL, O'Connor S. T cell-rich lymphoid infiltrates with large B cells: a review of key entities and diagnostic approach. J Clin Pathol. 2017; 70(3): 187-201, doi: 10.1136/jclinpath-2016-204065, indexed in Pubmed: 27895166.

17. Hartmann S. From a pathologist's point of view: Histiocytic cells in Hodgkin lymphoma and $\mathrm{T}$ cell/histiocyte rich large B cell lymphoma. Pathol Res Pract. 2015; 211(12): 901-904, doi: 10.1016/j. prp.2015.10.012, indexed in Pubmed: 26596262.

18. Tousseyn T, De Wolf-Peeters C. T cell/histiocyte-rich large B-cell lymphoma: an update on its biology and classification. Virchows Arch. 2011; 459(6): 557-563, doi: 10.1007/s00428-011-1165-Z, indexed in Pubmed: 22081105.

19. Martelli M, Ferreri AJM, Johnson P. Primary mediastinal large B-cell lymphoma. Crit Rev Oncol Hematol. 2008; 68(3): 256-263, doi: 10.1016/j.critrevonc.2008.07.020, indexed in Pubmed: 18774728 .

20. Martelli M, Di Rocco A, Russo E, et al. Primary mediastinal lymphoma: diagnosis and treatment options. Expert Rev Hematol. 2015; 8(2): 173-186, doi: 10.1586/17474086.2015.994604, indexed in Pubmed: 25537750.

21. Goodman A, Patel SP, Kurzrock R. PD-1-PD-L1 immune-checkpoint blockade in B-cell lymphomas. Nat Rev Clin Oncol. 2017; 14(4): 203-220, doi: 10.1038/nrclinonc.2016.168, indexed in Pubmed: 27805626 .

22. Yu Li, Li L, Medeiros LJ, et al. NF- B signaling pathway and its potential as a target for therapy in lymphoid neoplasms. Blood Rev. 2017; 31(2): 77-92, doi: 10.1016/j.blre.2016.10.001, indexed in Pubmed: 27773462.

23. Patrick LB, Mohile NA. Advances in Primary Central Nervous System Lymphoma. Curr Oncol Rep. 2015; 17(12): 60, doi: 10.1007/s11912-015-0483-8, indexed in Pubmed: 26475775.

24. Deckert M, Brunn A, Montesinos-Rongen M, et al. Primary lymphoma of the central nervous system--a diagnostic challenge. Hematol Oncol. 2014; 32(2): 57-67, doi: 10.1002/hon.2087, indexed in Pubmed: 23949943.

25. Deckert M, Montesinos-Rongen M, Brunn A, et al. Systems biology of primary CNS lymphoma: from genetic aberrations to modeling in mice. Acta Neuropathol. 2014; 127(2): 175-188, doi: 10.1007/s00401-013-1202-x, indexed in Pubmed: 24240734.

26. Sugita $\mathrm{Y}$, Muta H, Ohshima K, et al. Primary central nervous system lymphomas and related diseases: pathological characteristics and discussion of the differential diagnosis. Neuropathology. 2016; 36(4): 313-324, doi: 10.1111/neup.12276, indexed in Pubmed: 26607855.

27. Castillo JJ, Beltran BE, Miranda RN, et al. EBV-positive diffuse large B-cell lymphoma of the elderly: 2016 update on diagnosis, risk-stratification, and management. Am J Hematol. 2016; 91(5): 529-537, doi: 10.1002/ajh.24370, indexed in Pubmed: 27093913.
28. Ghosh Roy S, Robertson ES, Saha A. Epigenetic impact on EBV associated B-cell lymphomagenesis. Biomolecules. 2016; 6(4), doi: 10.3390/biom6040046, indexed in Pubmed: 27886133.

29. Castillo J, Pantanowitz L, Dezube BJ. HIV-associated plasmablastic lymphoma: lessons learned from 112 published cases. Am J Hematol. 2008; 83(10): 804-809, doi: 10.1002/ajh.21250, indexed in Pubmed: 18756521.

30. Harmon CM, Smith LB. Plasmablastic lymphoma: a review of clinicopathologic features and differential diagnosis. Arch Pathol Lab Med. 2016; 140(10): 1074-1078, doi: 10.5858/arpa.20160232-RA, indexed in Pubmed: 27684979.

31. Liu JJ, Zhang L, Ayala E, et al. Human immunodeficiency virus (HIV)-negative plasmablastic lymphoma: a single institutional experience and literature review. Leuk Res. 2011; 35(12): 1571-1577, doi: 10.1016/j.leukres.2011.06.023, indexed in Pubmed: 21752466 .

32. Colomo L, Loong F, Rives S, et al. Diffuse large B-cell lymphomas with plasmablastic differentiation represent a heterogeneous group of disease entities. Am J Surg Pathol. 2004; 28(6): 736-747, indexed in Pubmed: 15166665.

33. Gonzalez-Farre B, Martinez D, Lopez-Guerra M, et al. HHV8-related lymphoid proliferations: a broad spectrum of lesions from reactive lymphoid hyperplasia to overt lymphoma. Mod Pathol. 2017; 30(5): 745-760, doi: 10.1038/modpathol.2016.233, indexed in Pubmed: 28084335.

34. Montes-Moreno S, Montalbán C, Piris MA. Large B-cell lymphomas with plasmablastic differentiation: a biological and therapeutic challenge. Leuk Lymphoma. 2012; 53(2): 185-194, doi: 10.310 9/10428194.2011.608447, indexed in Pubmed: 21812534.

35. Pan Z, Hu S, Li M, et al. ALK-positive large B-cell lymphoma: a clinicopathologic study of 26 cases with review of additional 108 cases in the literature. Am J Surg Pathol. 2017; 41(1): 25-38, doi: 10.1097/PAS.0000000000000753, indexed in Pubmed: 27740969 .

36. Sakamoto K, Nakasone H, Togashi Y, et al. ALK-positive large B-cell lymphoma: identification of EML4-ALK and a review of the literature focusing on the ALK immunohistochemical staining pattern. Int J Hematol. 2016; 103(4): 399-408, doi: 10.1007/ /s12185-016-1934-1, indexed in Pubmed: 26781614.

37. Cai Q, Medeiros LJ, Xu X, et al. MYC-driven aggressive B-cell lymphomas: biology, entity, differential diagnosis and clinical management. Oncotarget. 2015; 6(36): 38591-38616, doi: 10.18632/ /oncotarget.5774, indexed in Pubmed: 26416427.

38. Dunleavy K, Little RF, Wilson WH. Update on Burkitt lymphoma. Hematol Oncol Clin North Am. 2016; 30(6): 1333-1343, doi: 10.1016/j.hoc.2016.07.009, indexed in Pubmed: 27888884.

39. Schmitz R, Young RM, Ceribelli M, et al. Burkitt lymphoma pathogenesis and therapeutic targets from structural and functional genomics. Nature. 2012; 490(7418): 116-120, doi: 10.1038/ /nature11378, indexed in Pubmed: 22885699.

40. Iqbal J, Naushad H, Bi C, et al. Genomic signatures in B-cell lymphoma: how can these improve precision in diagnosis and inform prognosis? Blood Rev. 2016; 30(2): 73-88, doi: 10.1016/j. blre.2015.08.002, indexed in Pubmed: 26432520.

41. Lynch RC, Gratzinger D, Advani RH, et al. Clinical impact of the 2016 update to the WHO Lymphoma Classification. Curr Treat Options Oncol. 2017; 18(7): 45, doi: 10.1007/s11864-017-0483-z, indexed in Pubmed: 28670664.

42. Grygalewicz B, Woroniecka R, Rymkiewicz G, et al. The 11qgain/loss aberration occurs recurrently in MYC-negative 
Burkitt-like lymphoma with 11q aberration, as well as MYC-positive Burkitt lymphoma and MYC-positive high-grade B-cell lymphoma, NOS. Am J Clin Pathol. 2017; 149(1): 17-28, doi: 10.1093/ /ajcp/aqx139, indexed in Pubmed: 29272887.

43. Rymkiewicz G, Grygalewicz B, Chechlinska M, et al. A comprehensive flow-cytometry-based immunophenotypic characterization of Burkitt-like lymphoma with 11q aberration. Mod Pathol. 2018 [Epub ahead of print], doi: 10.1038/modpathol.2017.186, indexed in Pubmed: 29327714.

44. Salaverria I, Martin-Guerrero I, Wagener R, et al. Molecular mechanisms in Malignant Lymphoma Network Project, Berlin-Frankfurt-Münster Non-Hodgkin Lymphoma Group. A recurrent $11 \mathrm{q}$ aberration pattern characterizes a subset of MYC-negative high-grade B-cell lymphomas resembling Burkitt lymphoma. Blood. 2014; 123(8): 1187-1198, doi: 10.1182/ /blood-2013-06-507996, indexed in Pubmed: 24398325.

45. Li S, Desai P, Lin P, et al. MYC/BCL6 double-hit lymphoma (DHL): a tumour associated with an aggressive clinical course and poor prognosis. Histopathology. 2016; 68(7): 1090-1098, doi: 10.1111/his.12884, indexed in Pubmed: 26426741.

46. Li S, Weiss VL, Wang XJ, et al. High-grade B-cell lymphoma with MYC rearrangement and without BCL2 and BCL6 rearrangements is associated with high P53 expression and a poor prognosis. Am J Surg Pathol. 2016; 40(2): 253-261, doi: 10.1097/ /PAS.0000000000000542, indexed in Pubmed: 26448193.

47. Pillai RK, Sathanoori M, Van Oss SB, et al. Double-hit B-cell lymphomas with BCL6 and MYC translocations are aggressive, frequently extranodal lymphomas distinct from BCL2 double-hit B-cell lymphomas. Am J Surg Pathol. 2013; 37(3): 323-332, doi: 10.1097/PAS.0b013e31826cebad, indexed in Pubmed: 23348205 .

48. Swerdlow SH. Diagnosis of ,double hit' diffuse large B-cell lymphoma and B-cell lymphoma, unclassifiable, with features intermediate between DLBCL and Burkitt lymphoma: when and how, FISH versus IHC. Hematology Am Soc Hematol Educ Program. 2014; 2014(1): 90-99, doi: 10.1182/asheducation-2014.1.90, indexed in Pubmed: 25696840.

49. Yoshida M, Ichikawa A, Miyoshi H, et al. Clinicopathological features of double-hit B-cell lymphomas with MYC and BCL2, BCL6 or CCND1 rearrangements. Pathol Int. 2015; 65(10): 519-527, doi: 10.1111/pin.12335, indexed in Pubmed: 26224092.

50. Sesques P, Johnson NA. Approach to the diagnosis and treatment of high-grade B-cell lymphomas with MYC and BCL2 and/or BCL6 rearrangements. Blood. 2017; 129(3): 280-288, doi: 10.1182/ /blood-2016-02-636316, indexed in Pubmed: 27821509.

51. Rosenthal A, Younes A. High grade B-cell lymphoma with rearrangements of MYC and BCL2 and/or BCL6: Double hit and triple hit lymphomas and double expressing lymphoma. Blood Rev. 2017; 31(2): 37-42, doi: 10.1016/j.blre.2016.09.004, indexed in Pubmed: 27717585.

52. Campo E. MYC in DLBCL: partners matter. Blood. 2015; 126(22): 2439-2440, doi: 10.1182/blood-2015-10-671362, indexed in Pubmed: 26612895 .

53. Menon MP, Pittaluga S, Jaffe ES. The histological and biological spectrum of diffuse large B-cell lymphoma in the World Health Organization classification. Cancer J. 2012; 18(5): 411-420, doi: 10.1097/PPO.0b013e31826aee97, indexed in Pubmed: 23006945 .

54. Rentas Torres Y, Rodríguez-López JL, Valentin M, et al. Difficult diagnosis between B cell lymphoma and classical Hodgkin's lymphoma. Bol Asoc Med P R. 2015; 107(3): 98-101, indexed in Pubmed: 26742206.

55. Nicolae A, Pittaluga S, Abdullah S, et al. EBV-positive large B-cell lymphomas in young patients: a nodal lymphoma with evidence for a tolerogenic immune environment. Blood. 2015; 126(7): 863-872, doi: 10.1182/blood-2015-02-630632, indexed in Pubmed: 25999451.

56. Calvo KR, Traverse-Glehen A, Pittaluga S, et al. Molecular profiling provides evidence of primary mediastinal large B-cell lymphoma as a distinct entity related to classic Hodgkin lymphoma: implications for mediastinal gray zone lymphomas as an intermediate form of B-cell lymphoma. Adv Anat Pathol. 2004; 11(5): 227-238, indexed in Pubmed: 15322489.

57. Rodig SJ, Savage KJ, LaCasce AS, et al. Expression of TRAF1 and nuclear c-Rel distinguishes primary mediastinal large cell lymphoma from other types of diffuse large B-cell lymphoma. Am J Surg Pathol. 2007; 31(1): 106-112, doi: 10.1097/01. pas.0000213334.40358.0e, indexed in Pubmed: 17197926.

58. Eberle FC, Salaverria I, Steidl C, et al. Gray zone lymphoma: chromosomal aberrations with immunophenotypic and clinical correlations. Mod Pathol. 2011; 24(12): 1586-1597, doi: 10.1038/ /modpathol.2011.116, indexed in Pubmed: 21822207.

59. Evens AM, Kanakry JA, Sehn LH, et al. Gray zone lymphoma with features intermediate between classical Hodgkin lymphoma and diffuse large B-cell lymphoma: characteristics, outcomes, and prognostication among a large multicenter cohort. Am J Hematol. 2015; 90(9): 778-783, doi: 10.1002/ajh.24082, indexed in Pubmed: 26044261.

60. Dunleavy K, Wilson WH. Primary mediastinal B-cell lymphoma and mediastinal gray zone lymphoma: do they require a unique therapeutic approach? Blood. 2015; 125(1): 33-39, doi: 10.1182/ /blood-2014-05-575092, indexed in Pubmed: 25499450.

61. Wilson WH, Pittaluga S, Nicolae A, et al. A prospective study of mediastinal gray-zone lymphoma. Blood. 2014; 124(10): 1563-1569, doi: 10.1182/blood-2014-03-564906, indexed in Pubmed: 25024303.

62. A clinical evaluation of the International Lymphoma Study Group classification of non-Hodgkin's lymphoma. The Non-Hodgkin's Lymphoma Classification Project. Blood. 1997; 89(11): 3909-3918, indexed in Pubmed: 9166827.

63. Vose JM. Mantle cell lymphoma: 2017 update on diagnosis, risk-stratification, and clinical management. Am J Hematol. 2017; 92(8): 806-813, doi: 10.1002/ajh.24797, indexed in Pubmed: 28699667.

64. Beà S, Amador V. Role of SOX11 and genetic events cooperating with cyclin D1 in mantle cell lymphoma. Curr Oncol Rep. 2017; 19(6): 43, doi: 10.1007/s11912-017-0598-1, indexed in Pubmed: 28466437.

65. Lu TX, Li JY, Xu W. The role of SOX11 in mantle cell lymphoma. Leuk Res. 2013; 37(11): 1412-1419, doi: 10.1016/j.leukres.2013.07.039, indexed in Pubmed: 24001358.

66. Zlamalikova L, Moulis M, Salek D, et al. Expression of D-type cyclins in mantle cell and diffuse large B-cell lymphomas. Oncol Rep. 2016; 35(5): 2673-2680, doi: 10.3892/or.2016.4658, indexed in Pubmed: 26985765.

67. Dreyling M, Ferrero S, Vogt N, et al. European Mantle Cell Lymphoma Network. New paradigms in mantle cell lymphoma: is it time to risk-stratify treatment based on the proliferative signature? Clin Cancer Res. 2014; 20(20): 5194-5206, doi: 10.1158/10780432.CCR-14-0836, indexed in Pubmed: 25320369.

68. Martin P, Ghione P, Dreyling M. Mantle cell lymphoma - current standards of care and future directions. Cancer Treat Rev. 2017; 58: 51-60, doi: 10.1016/j.ctrv.2017.05.008, indexed in Pubmed: 28651117.

69. Onaindia A, Medeiros LJ, Patel KP. Clinical utility of recently identified diagnostic, prognostic, and predictive molecular biomarkers in mature B-cell neoplasms. Mod Pathol. 2017; 30(10): 1338-1366, doi: 10.1038/modpathol.2017.58, indexed in Pubmed: 28664939. 